\title{
Analisis Analitical Hierarchy Process Dalam Percepat Penyeleksian Penerimaan Tenaga Pendidik
}

\author{
Loneli Costaner ${ }^{1}$, Guntoro ${ }^{2}$, Febrizal Alfarasy ${ }^{3}$ \\ 1,2Program Studi Teknik Informatika Fakultas Ilmu Komputer Universitas Lancang Kuning \\ ${ }^{3}$ Program Studi Sistem Informasi Fakultas Ilmu Komputer Universitas Lancang Kuning \\ 1,2,3 Jl. Yos Sudarso KM. 8 Rumbai, Pekanbaru, Riau, telp. 08117532015 \\ e-mail: ${ }^{1}$ lonelicostaner@unilak.ac.id, ${ }^{2}$ guntoro@unilak.ac.id, ${ }^{3}$ febrizal@unilak.ac.id
}

\begin{abstract}
Abstrak
Sekolah khoiru ummah merupakan salah satu lembaga yang selalu berhubungan dengan tenaga pendidik sebagai aktor pertama dan tenaga kependidikan sebagai support organisasi. Permasalahan terjadi ketika harus menyeleksi calon tenaga pendidik, dimana banyaknya pelamar membuat proses penyeleksian dalam menentukan alternatif terbaik yang dilakukan masih dengan cara menimbang setiap skor secara manual diatas kertas. Kondisi tersebut terjadi kendala sulitnya untuk memutuskan calon tenaga pendidik yang sesuai kebutuhan dikarenakan harus menimbang dengan prasaan, kemudian proses keputusan juga masih lambat karena harus bermusyarawah yang cukup panjang dari personalia, kepala sekolah hingga yayasan demi konsistensi keputusan tepat untuk dipilih. Dengan demikian persoalan ini dibutuhkan suatu solusi proses keputusan yang relevan dan cepat dengan analisis metode Analytical hierarchy process $(A H P)$ dengan kriteria kelengkapan adminitrasi pelamar, ujian tertulis, penilaian personality, wawancara dan micro teaching. Sedangkan sampel data alternatif ada tiga pelamar yang akan dianalisis dengan metode AHP. Data nilai awal masukan didapatkan melalui quisioner perbandingan yang dinilai oleh personalia, kepala sekolah dan Yayasan dengan konsistensi kriteria 0.08 dimana nilai ini falid karena sesuai dengan kaedah konsistensi standar Thomas l.Saaty yaitu konsisten nilai $<0.1$. Pengujian ini dilakukan dengan langkah perhitungan consisten indek dan index random yang terdapat pada tahapan AHP kepada nilai masukan nilai tabel matrik perbandingan dari data alternatif. Hasil pengujian dengan nilai konsistensi seluruh data baik kriteria dan alternatif mendapatkan keputusan tebaik rekomendasi dengan nilai tertinggi didapatkan oleh Husen ahmad dengan nilai 0.729, kedua Sikin al hafidz dengan nilai 0.163 dan Sulaiman akhbar dengan nilai 0.109.
\end{abstract}

Kata kunci: Pendidik, Seleksi, Keputusan, Rekomendasi, Analitical Hierarchy Process

\begin{abstract}
The khoiru ummah school is one of the institutions that is always in touch with educators as the first actors and educational staff as organizational support. The problem occurs when it comes to selecting prospective teaching staff, where many applicants make a selection process in determining the best alternative which is still done by weighing each score manually on paper. In this condition, there is an obstacle in the difficulty of deciding the candidate for educators who are suitable for their needs because they have to weigh carefully, then the decision process is also still slow because they have to have a long discussion from personnel, principals to foundations for consistency in the right decision to be chosen. Thus, this problem requires a solution for the decision process that is relevant and fast by analyzing the Analytical Hierarchy Process (AHP) method with the criteria for completeness of applicant administration, written examinations, personality assessments, interviews and micro teaching. Meanwhile, the sample of alternative data were three applicants who were analyzed using the AHP method. Initial input value data were obtained through comparative questionnaires assessed by personnel, principals and foundations with the consistency of the criterion of 0.08 where this value was falid because it was in accordance with Thomas Laaty's standard consistency principle, which was consistent with a value of <0.1. This test is carried out by calculating the consisten index and random index contained in the AHP stage to the input
\end{abstract}


values of the comparison matrix table values from alternative data. The results of the test with the consistency value of all data, both criteria and alternatives, get the best recommendation with the highest value obtained by Husen Ahmad with a value of 0.729, both Sikin al Hafidz with a value of 0.163 and Sulaiman akhbar with a value of 0.109 .

Keywords: Educators, Selection, Decisions, Recommendations, Analytical Hierarchy Process.

\section{Pendahuluan}

Sekolah merupakan sarana untuk menimba ilmu, dimana siswa maupun siswi dapat mengikuti pembelajaran sesuai waktu pembelajaran yang telah ditetapkan oleh sekolah . Pentingnya sebuah pendidikan bagi anak membuat orang tua akan mencari tempat menimba ilmu yang terbaik untuk sang buah hati agar kelak ia menjadi generasi terbaik bermanfaat bagi ummat dan agama.

Sekolah Tahfidz Plus (STP) khairu ummah pekanbaru termasuk salah satu sekolah islami yang memiliki visi dan misi untuk memberikan pendidikan terbaik sesuai dengan kebutuhan masyarakat. STP Khoiru Ummah merupakan sekolah tahfizh dengan kurikulum mandiri berbasis aqidah Islam, kurikulum ini memiliki tujuan membentuk karakter kepribadian islam dan berjiwa pemimpin pada anak didik. Letak sekolah yang strategis beralamat Jl. Delima, Gang. Khoiru Ummah No. 3-6, Delima, Kec. Tampan, Kota Pekanbaru Prov. Riau sangat mudah dikenal oleh masyarakat bumi melayu. Dalam perjalanannya khairu ummah terus melakukan upaya meningkatkan kwalitas sumber daya manusia yaitu tenaga pendidik dalam memberikan pengajaran yang prima untuk memotivasi anak didik yang menimba ilmu disekolah [1].

Proses pembelajaran merupakan inti dari sebuah pendidikan, dimana peran pendidik atas anak didiknya harus saling berperan sehingga tercipta lingkungan belajar yang baik [2], hal ini juga termasuk dalam komponen belajar mengajar dimana seorang pendidik memiliki kemampuan mengembangkan pengajaranya baik didalam maupun diluar kelas [3].

Karena begitu pentingnya pendidikan tentunya membuat Yayasan khoiru ummah menempatkan para pendidik yang terbaik sehingga perlu adanya manajeman sumber daya manusia yang baik [4]. Dimasa pandemi covid 19 pendidik tidak hanya mampu mengajar namun juga harus bisa menggunakan teknologi dan sosmed dalam proses mengajarnya, seperti membuat video pembelajaran dan aplikasi aplikasi pembelajaran digital. Maka dari itu dalam menjaring tenaga pedidikan yang sesuai kriteria, maka setiap calon tenaga pendidik akan diseleksi dengan aturan penerimaan yang telah ditetapkan. Penerimaan berkas dilakukan ketika ada calon tenaga pendidik memasukkan berkas, kemudian berkas akan diseleksi, observasi personaliti, kemudian uji pengajaran, hafalan qur'an hingga wawancara, semua dilakukan dengan proses pencataan secara manual pada form yang sudah disiapkan oleh personalia. Proses yang dilakukan tersebut dirasakan oleh tim seleksi maupun yayasan kurang optimal karena penilaian terasa monoton. Begitu juga dalam penilaian akhir penskoran nilai, karena harus menghitung secara manual dimana kondisi ini menimbulkan lambatnya mendapatkan informasi untuk membuat keputusan akhir seleksi.

Menurut beberapa peneliti yang menggunakan metode AHP, [5] dalam desain sistem pedukung keputusan seleksi calon guru sekolah alam berbasis islam, penelitian yang dilakukan berbasis web dengan kriteria penilaian bobot terendah $8 \%$ bobot wawancara, 11,3\% bobot skill, $13.4 \%$ bobot akademik, $33.4 \%$ bobot magang dan $34.1 \%$ bobot sikap dimana hasil yang didapat cukup akurat. Menurut [6] dengan sistem penunjang keputusan penerimaan guru berbasis web, ia mengatakan bahwa penyeleksian guru yang dibuat dengan metode AHP berbasis web sangat efektif untuk mendapatkan keputusan. Menurut [7] dengan penerapan metode AHP sebagai penunjang keputusan penerimaan karyawan pada PT. Arkonin, didapatkan sebuh keputusan yang sesuai dengan kriteria yang diharapkan yaitu dari 3 calon karyawan, dimana score tertinggi adalah score calon karyawan B dengan bobot $37.2 \%$, kedua didapatkan oleh calon karyawan A bobot $37 \%$ dan trakhir calon bobot 10.5, menurut [8] dengan menerapka metode AHP untuk memilih guru berprestasi pada SD sangat mempermudah dan mempercepat keputusan dari 
empat alternative dihasilkan yang sangat direkomentasikan yaitu tri widyastuty dengan nilai 5.53, menurut [9] dengan menerapkan metode AHP untuk pemilihan guru berprestasi dapat menghindari konflik antar guru dengan hasil tertinggi persentasi 0.248 bernama tati sunarti, menurut [10] dengan menerapkan metode ahp untuk penerimaan guru honorer dapat mempercepat pemilihan calon guru honorer, menurut [11] dengan menerapkan metode AHP dapat mempermudah mencari guru yang terbaik degang hasil yang akurat, menurut [12] dalam penerapan metode ahp dalam menyeleksi guru baru Teknik Informatika yang mempermudah dalam prangkingan dengan nilai akhir 0.358 , menurut [13] dengan menerapkan metode ahp berbasis web untuk mendapatkan keputusan yang cepat untuk memperoleh siapa kinerja guru yang terbaik sangat efektif, dimana yang mendapatkan penilaian tertinggi dari proses ahp ini dengan nip G1683 yang bernama Sastro dengan nilai tertinggi 1.000.

Dalam uraian penelitian penelitian sebelumnya dapat disimpulkan pengambilan keputusan untuk penerimaan tenaga pendidik menggunakan suatu metode keputusan AHP dapat mempercepat proses pengambilan keputusan dengan konsisten. Selain tempat penelitian yang sangat membutuhkan sebuah metode sistem pengambilan keputusan, terdapat pengembagan sasaran keputusan dengan metode AHP pada sekolah berbasis home schooling yang tergolong jenis sekolah yang tampil untuk menjawab kebutuhan orang tua terhadap sekolah berbasis aqidah dengan kriteria khusus mitra. Sebenarnya ada beberapa cara untuk mendapatkan keputusan yang dapat mengakomodir proses penyeleksian calon tenaga pendidik dan karyawan, semua penilaian kritria dapat direcord dalam sebuah metode yang sangat sederhana namun memiliki peran yang besar bagi pembuat keputusan yaitu dengan metode Analitical hierarcy proses dimana hasil score akhir berupa prangkingan dari urutan tertinggi hingga urutan terendah [14]. Penelitian ini bertujuan untuk meminimalisir kesalahan dan mempercepat pembuat keputusan dengan Analisis analytical hierarcy process.

Dalam penelitian pemilihan guru dengan metode yang sama pernah dipublikasikan oleh peneliti sebelumnya dengan 3 kriteria, Nilai Pisikotes, Nilai Microteaching dan Wawancara, dimana indek konsisten yang didapat $0.009 \%$ sedangkan indek ratio nya $0.016 \%$ [12]. Dalam Penelitian ini dilakukan pengembangan berupa penambahan kriteria menjadi, administrasi, Personality, tertulis (psikotest), wawancara dan Microteaching, sehingga hasil yang didapat dalam pengembangan ini akan mengakomodir kebutuhan kebutuhan system dalam penyeleksian guru. Dengan matrik perbandingan nilai masukan yang diberikan akan dinormalisasi oleh system untuk mendapatkan bobot dan konsistensi keputusan.

\section{Metode Penelitian}

Dalam penelitian terdapat metode penelitian sebagai tahapan untuk mendapatkan keputusan, berikut metode atau tahapan yang diterapkan dalam penelitian;

\subsection{Mendefenisikan masalah}

Peneliti melakukan pra wawancara dan observasi ditempat lembaga mitra mengetahui bagaiaman system penerimaan tenaga pendidik yang sudah dilakukan sebelumnya. Terdapat kendala pada penyeleksian penerimaan tenaga pendidik yang mana masih dilakukan secara pertimbangan prasaan dan kalkulasi rata rata nilai secara manual diatas form kertas. Sehingga masih perlu dipertimbangkan oleh pihak Yayasan dengan musyawarah yang cukup panjang agar didapatkan tenaga pendidik yang diharapkan

\subsection{Menganalisa masalah}

Setelah ditetapkan masalah mitra, didapatkan solusi penyelesaian agar pertimbangan keputusan bisa dilakukan secara rasional dan memiliki standar hitung yang jelas maka dibutuhkan metode yang mampu mengakomodir dengan sistem keputusan sedangkan untuk mempercepat menghitung bobot nilai dan prangkingan dengan metode analytical hierarchy process.

\subsection{Pengumpulan data}

Pengumpulan data dilakukan untuk menambah referensi dan kemantapan metode yang digunakan untuk mempercepat keputusan. Pengumpulan data dilakukan diperpustakan maupun dilapangan sangat dibutuhkan dalam mempercepat mendapatkan data yang dibutuhkan. 
Terdapat ada 5 kriteria dan 3 alternatif. Adapun data yang dibutuhkan untuk menganalisis permasalahan adalah sebagai berikut;

1. Data kriteria

Adapun data kritria yang didapat dari tempat penelitian berdasarkan observasi yang dilakukan pada mitra dapat dilihat pada tabel dibawah 1. Sedangkan proses penilaian kriteri berdasarkan prosedur yang telah ditentukan berdasarkan wawancara kepada pihak personalia dan yayasan, dengan prosedur ada pada tabel 2

Tabel 1. Data kriteria tenaga pendidik

\begin{tabular}{|c|c|c|c|}
\hline No & $\begin{array}{c}\text { Nama } \\
\text { Kriteria }\end{array}$ & $\begin{array}{c}\text { Kode } \\
\text { kriteria }\end{array}$ & Keterangan \\
\hline 1 & Administrasi & $\mathrm{AD}$ & $\begin{array}{l}\text { Kriteria penilaian ini berkenaan dengan } \\
\text { kelengkapan administrasi atau kesesuaian calon } \\
\text { tenaga pendidik terhadap kebutuhan sekolah }\end{array}$ \\
\hline 2 & Tertulis & $\mathrm{TT}$ & $\begin{array}{l}\text { Kriteria penilaian ini berkenaan hasil test terulis } \\
\text { berupa soal soal yang dijawab oleh calon tenaga } \\
\text { pendidik }\end{array}$ \\
\hline 3 & Personality & PS & $\begin{array}{l}\text { Kriteria penilaian ini berkenaan dengan } \\
\text { kepribadian calon tenaga pendidik pada saat } \\
\text { intraksi selama proses penilaian }\end{array}$ \\
\hline 4 & Wawancara & WW & $\begin{array}{l}\text { Kriteria penilaian ini berkenaan atas jawaban } \\
\text { jawaban atas pertanyaan secara langsung kepada } \\
\text { calon tenaga pendidik }\end{array}$ \\
\hline 5 & $\begin{array}{l}\text { Micro } \\
\text { teaching }\end{array}$ & MT & $\begin{array}{l}\text { Kriteria penilian ini berkenaan dengan kemapuan } \\
\text { calon tenaga pendidik mengajarkan pengajaran } \\
\text { singkat dan ditempat terbatas }\end{array}$ \\
\hline
\end{tabular}

Tabel 2. Ketrangan penilitian

\begin{tabular}{|c|c|c|c|}
\hline NO & KRITERIA & $\begin{array}{c}\text { RANGE } \\
\text { NILAI }\end{array}$ & KETERANGAN \\
\hline
\end{tabular}

$1 \quad$ Administrasi Lengkap

Sedang

Tidak Lengkap

2 Ujian tertulis

$80-100$

$70-79$

$60-69$

$50-59$

$0-49$

3 Personality
Administrasi Lengkap apabila data persyaratan sesuai dengan kebutuhan tenaga pendidik, Ijazah $\mathrm{S} 1$, Sesuai dengan jurusan, Sertifikat kompentensi

Administrasi Sedang, apabila tidak memiliki sertifikat pendukung

administrasi tidak lengkap, apabila tidak sesuai dengan jurusan yang dibutuhkan dan tidak memiliki sertifitkat pendukung

Dapat mengerjakan soal dengan sangat baik

Dapat mengerjakan soal dengan baik

Dapat mengerjakan soal cukup baik

Kurang memahami soal

tidak memahami soal

Disiplin, rapi, sopan, ramah, kooperatif dan komunikatif

Disiplin, rapi, Ramah dan komunikatif 
Cukup Baik

Disiplin, rapi, sopan

\begin{tabular}{|c|c|c|c|}
\hline \multirow[t]{3}{*}{4} & Wawancara & $80-100$ & Komunikasi sangat lancar \\
\hline & & $60-79$ & Komunikasi lancar \\
\hline & & $0-69$ & Komunikasi kurang lancar \\
\hline NO & KRITERIA & $\begin{array}{l}\text { RANGE } \\
\text { NILAI }\end{array}$ & KETERANGAN \\
\hline \multirow[t]{3}{*}{5} & $\begin{array}{l}\text { Micro } \\
\text { theacing }\end{array}$ & $80-100$ & $\begin{array}{l}\text { Penyampaian sistematis, semangat dan menguasai } \\
\text { ruang }\end{array}$ \\
\hline & & $60-79$ & Penyampaian sistematis, semangat \\
\hline & & $0-69$ & Penyampaian sistematis \\
\hline
\end{tabular}

Sumber bahan: wawancara dan dokumen mitra tahun 2020

2. Data alternatif

Berikut data alternatif yang dianalsis menggunakan metode analytical hierarchy process;

Tabel 3. Data alternatif

\begin{tabular}{ccccccc}
\hline No & $\begin{array}{c}\text { Nama } \\
\text { alternatif }\end{array}$ & \multicolumn{5}{c}{ Data Alternatif per kriteria } \\
\hline & & AD & TT & PS & WW & MT \\
\hline $\mathbf{1}$ & $\begin{array}{c}\text { Husen } \\
\text { Ahmad }\end{array}$ & Lengkap & 80 & $\begin{array}{c}\text { Sangat } \\
\text { baik }\end{array}$ & 90 & 85 \\
$\mathbf{2}$ & $\begin{array}{c}\text { Sikin } \\
\text { Alhafidz }\end{array}$ & Sedang & 90 & Baik & 87 & 80 \\
$\mathbf{3}$ & $\begin{array}{c}\text { Sulaiman } \\
\text { akbar }\end{array}$ & Lengkap & 75 & Baik & 80 & 85 \\
\hline
\end{tabular}

\subsection{Analitical Hierarchy Process}

Ada beberapa tahapan dalam menyelesikan permasalahan dengna menggunakan metode AHP [15]:

a. Mendefenisikan permasalahan dan bagaimana menentukan solusi yang diharapkan dengan memetakan konsep hierarki

b. Membangun struktur hirarki, dengan goal atau sebuah tujuan yang diharapkan pada level 1 kemudian kriteri dari tujuan pada level 2 dan akternatif yang akan terpilih pada tujuan akhir pada level 3 .

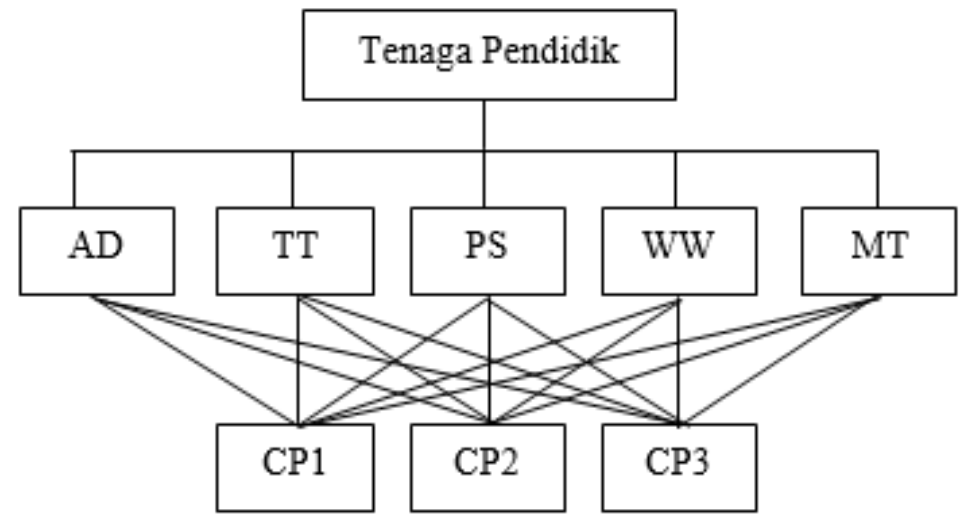

Gambar 1. Hierarki tenaga pendidik 
c. Membuat matrik perbandingan berpasangan, dimana matrik ini menggambarkan kontribusi relative atau adanya pengaruh pada setiap elemen terhadap tujuan atau kriteria yang setingkat diatasnya. Penilaian ini dilakukan berdasarkan seberapa besar tingkat kepentingan antara elemen satu dengan elemen yang lain menggunakan tabel saaty sebagai berikut.

Tabel 4. Intensitas kepentingan Saaty

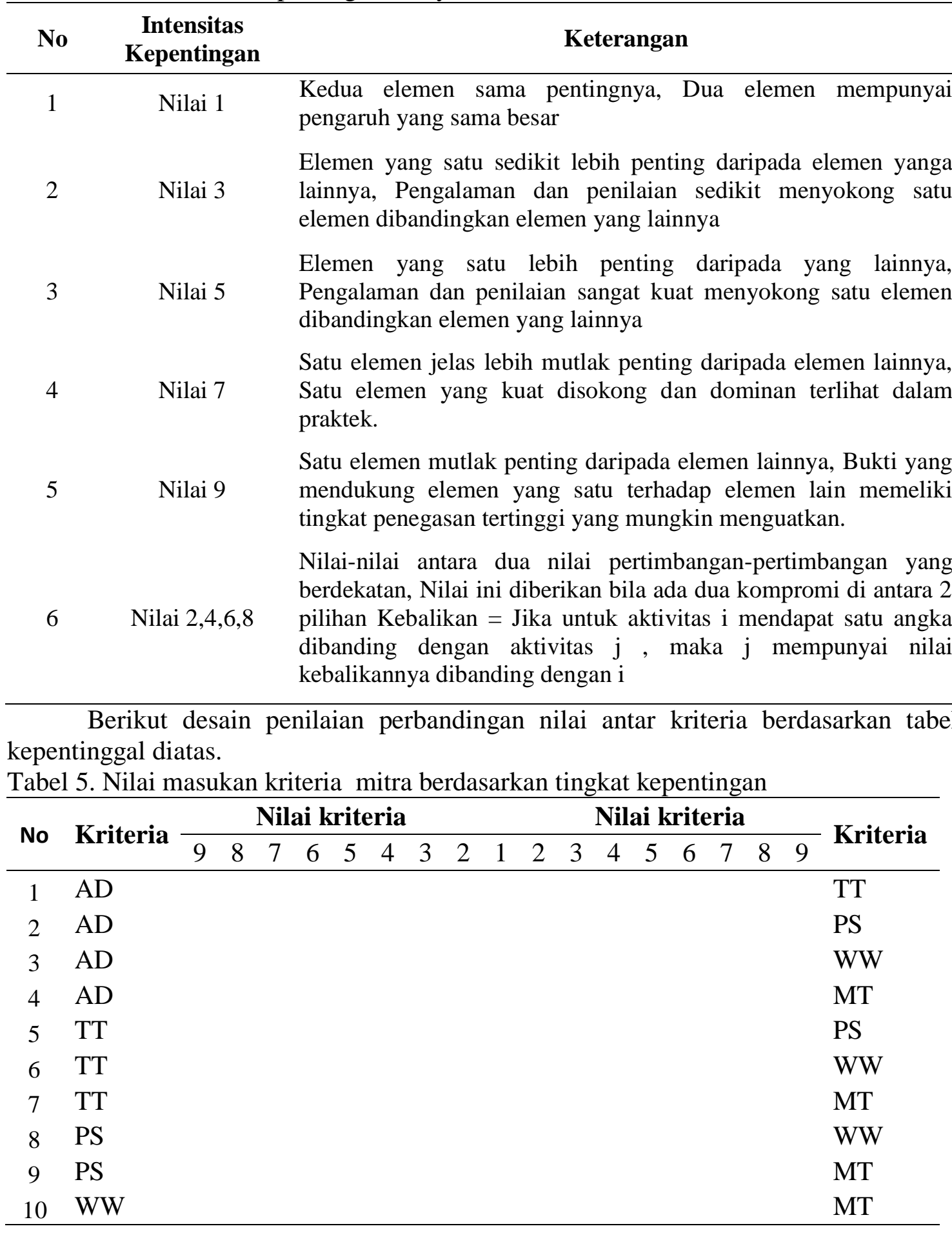


d. Menormalkan data dengan membagi nilai yang berpasangan dengan nilai total setiap kolom hasil perbandingan.

e. Menghitung nilai eigen vector dan menguji konsistensinya dibawah $0.1 \%$, jika kemudian ada nilai yang tidak konsisten maka pengambilan data sebagai input perlu diulangi.

$\mathrm{CI}=$ Consisten Indek

$$
C I \frac{\lambda_{\text {maksimum }-n}}{n-1}
$$

Max = Jumlah rata rata lamda

$\mathrm{N}=$ jumlah kriteria

f. Menguji konsistensi hirarki, jika tidak memenuhi syarat $\mathrm{CR}<0.100$, maka penilaian harus diulangi. Setelah menguji konsistensi indek, langkah selanjutnya menguji konsistensi data masukan yang diberi oleh pihak yang bertanggung jawab terhadap nilai data masukan tersebut, jika nilai konsistensinya dibawah 0.1 maka data masukan konsisten namun jika nilai konsistensi nya bernilai diatas 0.1 maka diperlukan masukkan ulang nilai perbandingannya.

Rumusnya IR $=\mathrm{CI} / \mathrm{IR}$

$\mathrm{IR}=$ Indek random

$\mathrm{CI}=$ Konsisten Index

g. Untuk perbandingan alternatif sama tahapannya seperti tahapan perhitungan antar kriteria dimulai dari a sampai dengan $\mathrm{f}$

h. Perangkingan dilakukan dengan melakukan perkalian matrik bobot kriteria dengan bobot alternatif.

Rangking $=($ bobot prioritas $1 *$ bobot alternatif 1$)+($ bobot prioritas ..n $*$ bobot alternatif ..n)

\section{Hasil dan Pembahasan}

Pada tahap ini menjelaskan hasil dan pembahasan peneliti akan menguraikan tahapan proses analisis, nilai perbandingan hingga perangkingan, serta pengujian menggunakan aplikasi.

a. Hasil perbandingan antar kriteria

Berikut hasil perbandiangan antar kriteria berdasarkan tabel 2. Nilai perbandingan antar kriteria didapatkan dari mitra berdasarkan tingkat kepentingan antar kriteria.

Tabel 6. Nilai perbandingan antar kriteria

\begin{tabular}{clccccc}
\hline No & KODE & AD & TT & PS & WW & MT \\
\hline $\mathbf{1}$ & AD & 1 & 3 & 2 & 3 & 2 \\
$\mathbf{2}$ & TT & 0.333 & 1 & 1 & 1 & 2 \\
$\mathbf{3}$ & PS & 0.5 & 1 & 1 & 2 & 1 \\
$\mathbf{4}$ & WW & 0.333 & 1 & 0.5 & 1 & 3 \\
$\mathbf{5}$ & MT & 0.5 & 0.5 & 1 & 0.333 & 1 \\
Baris total & & 2.666 & 6.5 & 5.5 & 7.333 & 9
\end{tabular}

b. Menormalkan data dengan membagi nilai yang berpasangan dengan nilai total setiap kolom hasil perbandingan.

Tabel 7. Normalisasi matrik dan bobot prioritas 


\begin{tabular}{clrccccc}
\hline NO & KODE & \multicolumn{1}{c}{ AD } & TT & PS & WW & MT & $\begin{array}{c}\text { Bobot } \\
\text { Prioritas }\end{array}$ \\
\hline $\mathbf{1}$ & AD & 0.375 & 0.461538462 & 0.363636364 & 0.409090909 & 0.222222222 & 0.366297591 \\
$\mathbf{2}$ & TT & 0.125 & 0.153846154 & 0.181818182 & 0.136363636 & 0.222222222 & 0.163850039 \\
$\mathbf{3}$ & PS & 0.1875 & 0.153846154 & 0.181818182 & 0.272727273 & 0.111111111 & 0.181400544 \\
$\mathbf{4}$ & WW & 0.125 & 0.153846154 & 0.090909091 & 0.136363636 & 0.333333333 & 0.167890443 \\
$\mathbf{5}$ & MT & 0.1875 & 0.076923077 & 0.181818182 & 0.045454545 & 0.111111111 & 0.120561383 \\
\hline
\end{tabular}

Dalam tabel normalisai data kriteria diatas untuk mendapatkan bobot prioritas yang berfungsi untuk melihat bobot kritia mana yang lebih tinggi dan juga sebagai bobot untuk menentukan perangkingan akhir

Tabel 8. Konsistensi Matrik antar kriteria

\begin{tabular}{ccrccccc}
\hline NO & KODE & \multicolumn{1}{c}{ AD } & TT & PS & WW & MT & $\begin{array}{c}\text { Consistency } \\
\text { Measure }\end{array}$ \\
\hline $\mathbf{1}$ & AD & 0.375 & 0.461538462 & 0.363636364 & 0.409090909 & 0.222222222 & 2.859 .229 .994 \\
$\mathbf{2}$ & TT & 0.125 & 0.153846154 & 0.181818182 & 0.136363636 & 0.222222222 & 6.474 .451 .689 \\
$\mathbf{3}$ & PS & 0.1875 & 0.153846154 & 0.181818182 & 0.272727273 & 0.111111111 & 624.747 .015 \\
$\mathbf{4}$ & WW & 0.125 & 0.153846154 & 0.090909091 & 0.136363636 & 0.333333333 & 3.426 .973 .659 \\
$\mathbf{5}$ & MT & 0.1875 & 0.076923077 & 0.181818182 & 0.045454545 & 0.111111111 & 5.079 .067 .644 \\
\hline \multicolumn{2}{l}{ Lamda Max } & \multicolumn{2}{l}{ Rata rata CM } & & & & 1.395 .976 .039 \\
\hline
\end{tabular}

Untuk mencari konsistensi indek maka diperlukan nilai lamda max dengan cara menjumlahkan nilai consisten measure sebagaimana yang terlihat pada tabel 7. Konsisten matrik c. Menghitung nilai eigen vector dan menguji konsistensinya dibawah $0.1 \%$, jika kemudian ada nilai yang tidak konsisten maka pengambilan data sebagai input perlu diulangi.

$$
\begin{aligned}
& \mathrm{CI}=(13.95976039-5) /(5-1) \\
& \mathrm{CI}=0.085400
\end{aligned}
$$

Berdasarkan hasil pencarian indek konsistensi diatas, nilai CI dibawah $0.1 \%$ yaitu 0.085400 yang berarti nilai masukan tersebut konsisten sehingga tidak perlu diulang nilai perbandingannya. Setelah mencari konsistensi indek berikutnya mencari konsisten indek random $(\mathrm{CR})$.

i. Menguji konsistensi hirarki, jika tidak memenuhi syarakt $\mathrm{CR}<0.100$, maka penilaian harus diulangi.

Tabel 9. Index Random

\begin{tabular}{cccccccccc}
\hline NO & \multicolumn{1}{c}{ KET } & \multicolumn{1}{c}{ NILAI } \\
& $\mathbf{1}$ & Ordo Matrik & 1 & 2 & 3 & 4 & 5 & 6 & 7 \\
$\mathbf{2}$ & Ratio Index & 0 & 0 & 0.58 & 0.9 & 1.12 & 1.24 & 1.32 \\
\hline
\end{tabular}

Dikarenakan jumlah kriteria pada penelitian ini ada 5, maka nilai indek random yang diambil pada tabel diatas adalah 1.12 sedangkan nilai Consisten indek 0.085400 maka dapat dimasukkan kedalam rumus berikut ini.

$\mathrm{IR}=0.085400 / 1.12$

$\mathrm{IR}=0.076250$ atau dibulatkan menjadi 0.08 jika diambil 2 angka dibelakang koma. 
Dari pengujian konsistensi diatas, dimana analytical hierarchy process membari batasan sebuah masukan tersebut konsisten atau tidak konsisten. Dimana data masukan tidak konsisten apabila hasil IR di atas > 1.0. Sedangkan dari hasil perhitungan diatas dapat disimpulkan data masukkan sudah normal sehingga bisa dikatakan konsisten.

j. Menguji dan mencari bobot alternatif

1. Tabel perbandingan alternatif $\mathrm{AD}$

Berikut nilai perbandingan alternatif calon pendidik per kriteria Administrasi berdasarkan data alternatif kriteria administrasi yang diberikan oleh mitra, tabel penilaian perbandingan dapat dilihat dibawah ini;

Tabel 10. Nilai perbandingan alternatif kriteria AD

\begin{tabular}{clccc}
\hline No & Kode & CP1 & CP2 & CP3 \\
\hline $\mathbf{1}$ & CP1 & 1 & 7 & 5 \\
$\mathbf{2}$ & CP2 & 0.14 & 1 & 1 \\
$\mathbf{3}$ & CP3 & 0.2 & 1 & 1 \\
\hline & Baris total & 1.34 & 9 & 7 \\
\hline
\end{tabular}

Tabel 11. Normalisasi dan bobot AD

\begin{tabular}{ccclcc}
\hline No & Kode & CP1 & CP2 & CP3 & Bobot \\
\hline $\mathbf{1}$ & CP1 & 0,744681 & 0,777778 & 0,7142857 & 0.745 \\
$\mathbf{2}$ & CP2 & 0,106383 & 0,111111 & 0,1428571 & 0.120 \\
$\mathbf{3}$ & CP3 & 0,148936 & 0,111111 & 0,1428571 & 0.134 \\
\hline
\end{tabular}

2. Tabel perbandingan alternatif TT

Berikut nilai perbandingan alternatif calon pendidik per kriteria Tertulis berdasarkan data alternatif oleh mitra, tabel penilaian perbandingan dapat dilihat dibawah ini;

Tabel 12. Nilai perbandingan alternatif kriteria TT

\begin{tabular}{ccrrr}
\hline No & Kode & \multicolumn{1}{c}{ CP1 } & \multicolumn{1}{c}{ CP2 } & CP3 \\
\hline $\mathbf{1}$ & CP1 & 1 & 3 & 5 \\
$\mathbf{2}$ & CP2 & 0.333 & 1 & 2 \\
$\mathbf{3}$ & CP3 & 0.2 & 0.5 & 1 \\
\hline \multicolumn{2}{r}{ Baris total } & 1.533 & 4.5 & 8 \\
\hline
\end{tabular}

Tabel 13. Normalisasi dan bobot TT

\begin{tabular}{ccccrc}
\hline No & Kode & CP1 & CP2 & \multicolumn{1}{c}{ CP3 } & Bobot \\
\hline $\mathbf{1}$ & CP1 & 0,652174 & 0,666667 & 0,625 & 0.648 \\
$\mathbf{2}$ & CP2 & 0,217391 & 0,222222 & 0,25 & 0.220 \\
$\mathbf{3}$ & CP3 & 0,130435 & 0,111111 & 0,125 & 0.122 \\
\hline
\end{tabular}

3. Tabel perbandingan alternatif PS

Berikut nilai perbandingan alternatif calon pendidik per kriteria Personality berdasrkan data alternatif oleh mitra, tabel penilaian perbandingan dapat dilihat dibawah ini;

Tabel 14. Nilai perbandingan alternatif kriteria PS

\begin{tabular}{ccrrr}
\hline No & Kode & \multicolumn{1}{c}{ CP1 } & CP2 & \multicolumn{1}{c}{ CP3 } \\
\hline $\mathbf{1}$ & CP1 & 1 & 3 & 1 \\
$\mathbf{2}$ & CP2 & 0.333 & 1 & 0.5 \\
$\mathbf{3}$ & CP3 & 1 & 2 & 1 \\
\hline \multicolumn{2}{l}{ Baris total } & 2.333 & 6 & 2.5 \\
\hline
\end{tabular}


Tabel 15. Normalisasi dan bobot PS

\begin{tabular}{cllrrrr}
\hline No & Kode & CP1 & CP2 & CP3 & \multicolumn{1}{c}{ Bobot } \\
\hline $\mathbf{1}$ & CP1 & 0,428571 & 0,5 & 0,4 & 0.443 \\
$\mathbf{2}$ & CP2 & 0,142857 & 0,166667 & 0,2 & 0.160 \\
$\mathbf{3}$ & CP3 & 0,428571 & 0,333333 & & 0,4 & 0.388
\end{tabular}

4. Tabel perbandingan alternatif WW

Masukkan nilai perbandingan alternatif calon pendidik per kriteria Wawancara, berikut tabel penilaian perbandingannya;

Tabel 16. Nilai perbandingan alternatif kriteria WW

\begin{tabular}{ccrrr}
\hline No & Kode & \multicolumn{1}{c}{ CP1 } & \multicolumn{1}{c}{ CP2 } & \multicolumn{1}{c}{ CP3 } \\
\hline $\mathbf{1}$ & CP1 & 1 & 4 & 5 \\
$\mathbf{2}$ & CP2 & 0.25 & 1 & 0.5 \\
$\mathbf{3}$ & CP3 & 0.2 & 2 & 1 \\
\hline \multicolumn{2}{l}{ Baris total } & 1.45 & 7 & 6.5 \\
\hline
\end{tabular}

Tabel 17. Normalisasi dan bobot WW

\begin{tabular}{cllllr}
\hline No & Kode & CP1 & CP2 & CP3 & Bobot \\
\hline $\mathbf{1}$ & CP1 & 0,689655 & 0,571429 & 0,7692308 & 0.676 \\
$\mathbf{2}$ & CP2 & 0,172414 & 0,142857 & 0,0769231 & 0.131 \\
$\mathbf{3}$ & CP3 & 0,137931 & 0,285714 & 0,1538462 & 0.192 \\
\hline
\end{tabular}

5. Tabel perbandingan alternatif MT

Masukkan nilai perbandingan alternative calon pendidik per kriteria Mikro Teaching, berikut tabel penilaian perbandingannya;

Tabel 18. Nilai perbandingan alternatif kriteria MT

\begin{tabular}{ccrrr}
\hline No & Kode & \multicolumn{1}{c}{ CP1 } & \multicolumn{1}{c}{ CP2 } & CP3 \\
\hline $\mathbf{1}$ & CP1 & 1 & 6 & 5 \\
$\mathbf{2}$ & CP2 & 0.167 & 1 & 2 \\
$\mathbf{3}$ & CP3 & 0.2 & 0.5 & 1 \\
\hline \multicolumn{2}{l}{ Baris total } & 1.367 & 7.5 & 8 \\
\hline
\end{tabular}

Tabel 19. Normalisasi dan bobot WW

\begin{tabular}{cllrrr}
\hline No & Kode & CP1 & \multicolumn{1}{l}{ CP2 } & \multicolumn{1}{c}{ CP3 } & \multicolumn{1}{c}{ Bobot } \\
\hline $\mathbf{1}$ & CP1 & 0,731707 & 0,8 & 0,625 & 0.719 \\
$\mathbf{2}$ & CP2 & 0,121951 & 0,133333 & 0,25 & 0.168 \\
$\mathbf{3}$ & CP3 & 0,146341 & 0,066667 & 0,125 & 0.113 \\
\hline
\end{tabular}

Setelah pencarian bobot seluruh alternatif ditemukan, selanjutnya membuat perangkingan nilai untuk mendapatkan alternatif yang paling direkomendasikan atau alternatif nilai yang paling tinggi hingga alternatif dengan nilai yang paling rendah.

Tabel 20. Perangkingan calon pendidik

\begin{tabular}{lcrrrrrrr}
\hline & Alternatif & AD & TT & PS & WW & MT & Nilai & \\
\cline { 3 - 7 } No & $\begin{array}{c}\text { Bobot } \\
\text { prioritas }\end{array}$ & 0,366 & 0,164 & 0,181 & 0,16789 & 0,121 & $\begin{array}{c}\text { Rangking } \\
\end{array}$ \\
\hline $\mathbf{1}$ & CP1 & 0,746 & 0,648 & 0,443 & 0,676772 & 0,719 & $\mathbf{0 , 6 5 9 9 0 1}$ & $\mathbf{1}$ \\
$\mathbf{2}$ & CP2 & 0,12 & 0,23 & 0,17 & 0,130731 & 0,168 & $\mathbf{0 , 1 5 4 7 2 7}$ & $\mathbf{3}$ \\
$\mathbf{3}$ & CP3 & 0,134 & 0,122 & 0,387 & 0,192497 & 0,113 & $\mathbf{0 , 1 8 5 3 7 3}$ & $\mathbf{2}$ \\
\hline
\end{tabular}


Dari gambar diatas dapat dilihat bahwa nilai yang paling tinggi ada pada alternative CP1 yaitu ahmad husen dengan nilai 0,659901, untuk peringkat kedua pada CP3 yaitu Sulaiman Akbar dengan nilai 0,185373 dan untuk peringkat ketiga pada CP2 yaitu Sikin Alhafidz dengan nilai 0,154727. Berikutnya peneliti akan membahas pengujian menggunakan aplikasi experchoice sebagai aplikasi yang sangat direkomendasikan untuk memberikan informasi keakuratan analisis data diatas.

d. Pembahasan perbandingan Kriteria

Data penilaian perbandingan yang dimaksud adalah penilaian perbandingan kriteria dan alternatif dari persepsi mitra, dimana nilai perbandingan ini akan menjadi masukkan dalam aplikasi expert choice. Berikut pejelasannya;

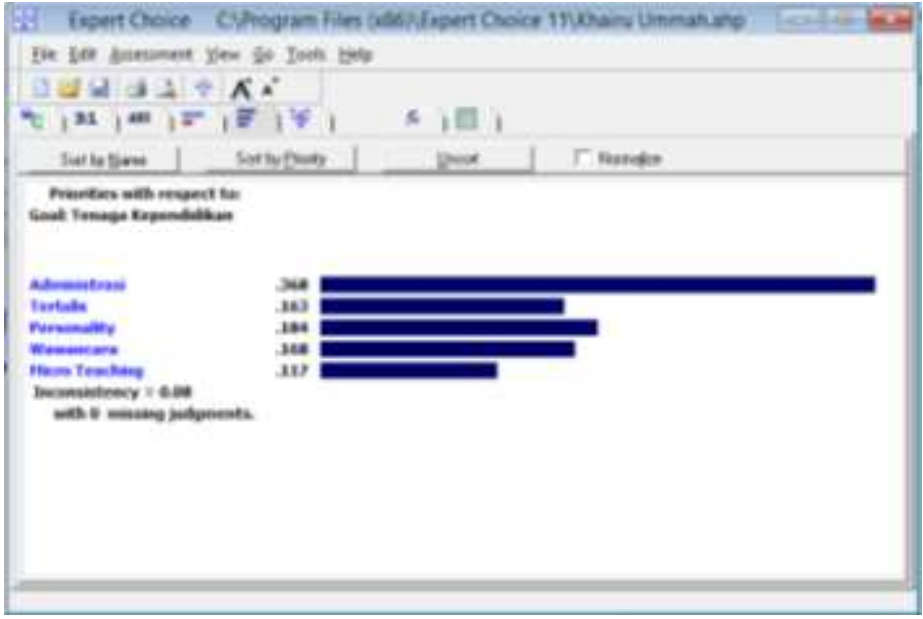

Gambar 2. Pengujian nilai konsistensi kriteria pada expert choice

Dari hasi pengujian masukan data perbandingan kriteria menggunakan aplikasi, maka bisa kita lihat bobot paling tinggi pada kriteria administrasi, kedua Personality, ketiga wawancara, keempat tertulis dan kelima mikcro teaching. Dimana data masukkan kriteria dianggap konsisten karena bernilai 0.08 dibawah 0.1. sehinga data tersebut layak untuk dilanjutkan untuk proses perangkingan.

e. Pembahasan antar alternatif pada kriteria Administrasi

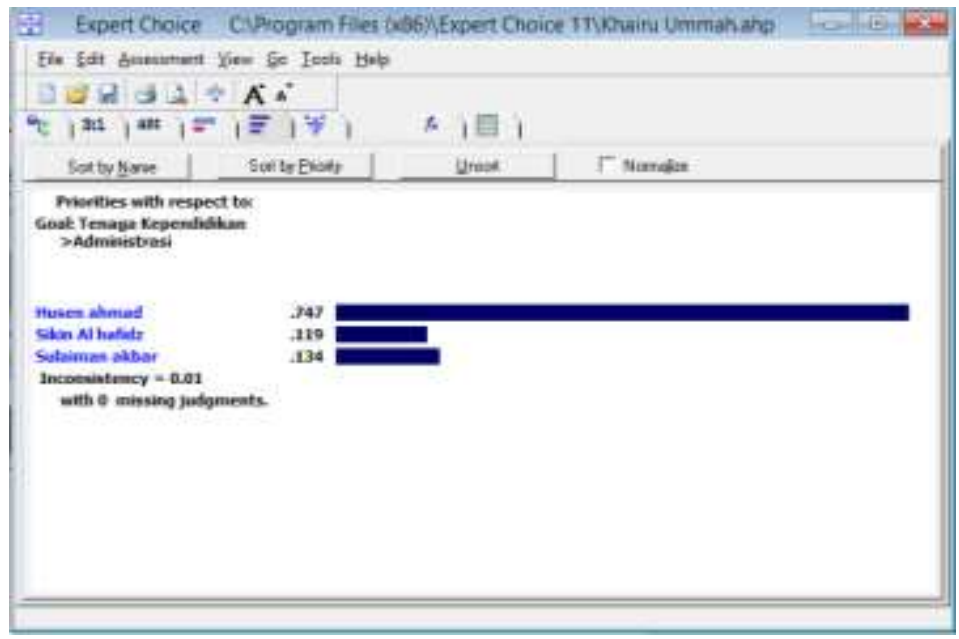

Gambar 3. Pengujian Konsistensi nilai administrasi pada Expert Choice

Dalam pengujian alternatif pada kriteria administrasi dapat dilihat yang memiliki bobot tertinggi adalah alternatif pertama Husen ahmad, kedua Sikin alhafidz, ketiga Sulaiman akbar. Dimana data masukan administrasi dianggap konsisten dikarenakan bernilai 0.01 yaitu dibawah 0.1 . Sehingga data tersebut layak digunakan untuk proses perangkingan 
f. Pembahasan nilai antar alternative pada kriteria Tertulis

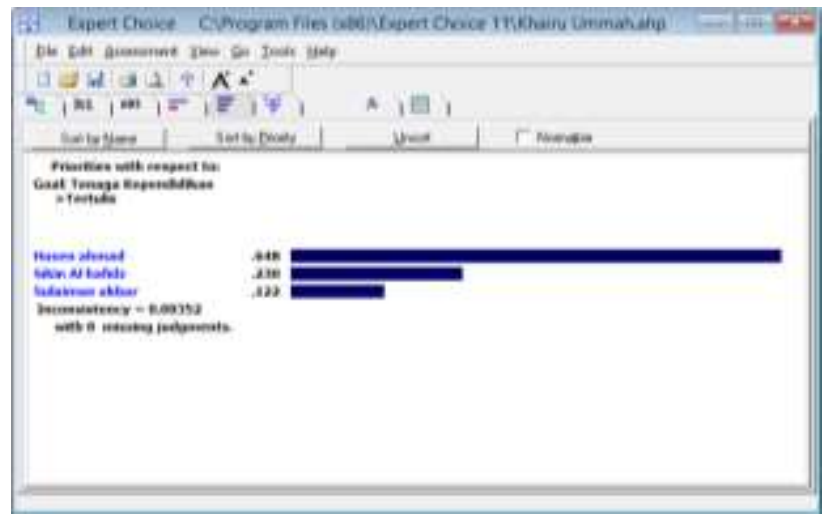

Gambar 4. Pengujian konsistensi nilai tertulis pada Expert Choice

Dalam pengujian alternatif pada kriteria tertulis dapat dilihat yang memiliki bobot tertinggi adalah alternatif pertama Husen ahmad, kedua Sikin alhafidz, ketiga Sulaiman akbar. Dimana data masukan administrasi dianggap konsisten dikarenakan bernilai 0.003 yaitu dibawah 0.1. Sehingga data tersebut layak digunakan untuk proses perangkingan

g. Pembahasan nilai antar alternative pada kriteria Personality

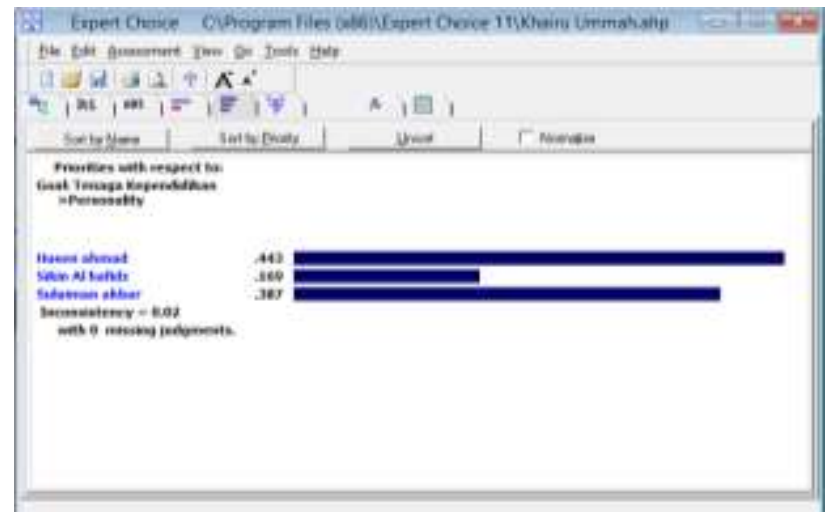

Gambar 5. Pengujian Konsistensi nilai alternatif Personality pada Expert Choice

Dalam pengujian alternatif pada kriteria personality dapat dilihat yang memiliki bobot tertinggi adalah alternatif pertama Husen ahmad, kedua Sulaiman akbar, ketiga Sikin alhafidz. Dimana data masukan administrasi dianggap konsisten dikarenakan bernilai 0.02 yaitu dibawah 0.1 . Sehingga data tersebut layak digunakan untuk proses perangkingan

h. Pembahasan nilai antar alternative pada kriteria Wawancara

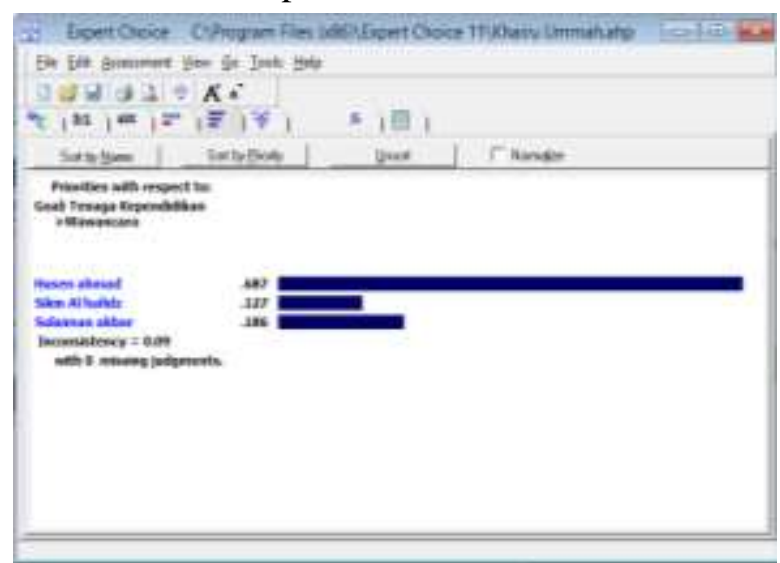

Gambar 6. Pengujian konsistensi nilai alternatif wawancara pada Expert Choice

Dalam pengujian alternatif pada kriteria wawancara dapat dilihat yang memiliki bobot tertinggi adalah alternatif pertama Husen ahmad, kedua Sulaiman akbar, ketiga Sikin alhafidz. 
Dimana data masukan administrasi dianggap konsisten dikarenakan bernilai 0.09 yaitu dibawah 0.1 . Sehingga data tersebut layak digunakan untuk proses perangkingan.

i. Pembahasan nilai antar alternative pada kriteria Micro teaching

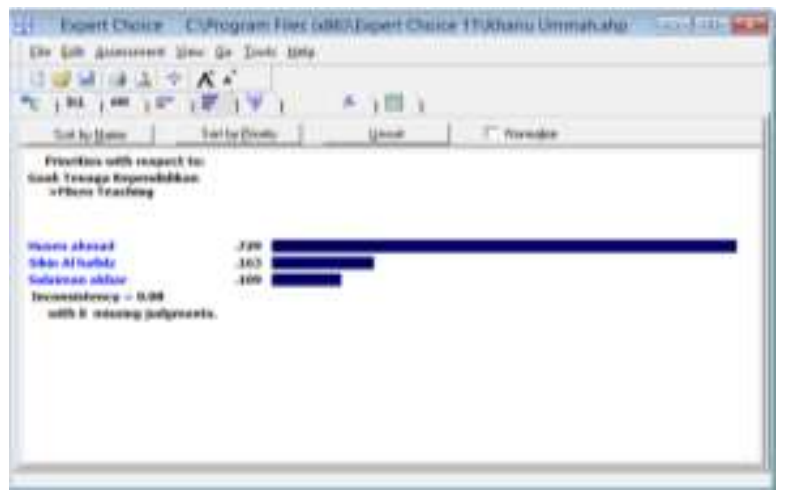

Gambar 7. Pengujian konsistensi nilai alternative Micro Teaching pada Expert Choice Dalam pengujian alternatif pada kriteria Micro Teaching dapat dilihat yang memiliki bobot tertinggi adalah alternatif pertama Husen ahmad, kedua Sikin alhafidz, ketiga Sulaiman akbar. Dimana data masukan administrasi dianggap konsisten dikarenakan bernilai 0.08 yaitu dibawah 0.1. Sehingga data tersebut layak digunakan untuk proses perangkingan.

j. Pembahasan Perangkingan pendidik

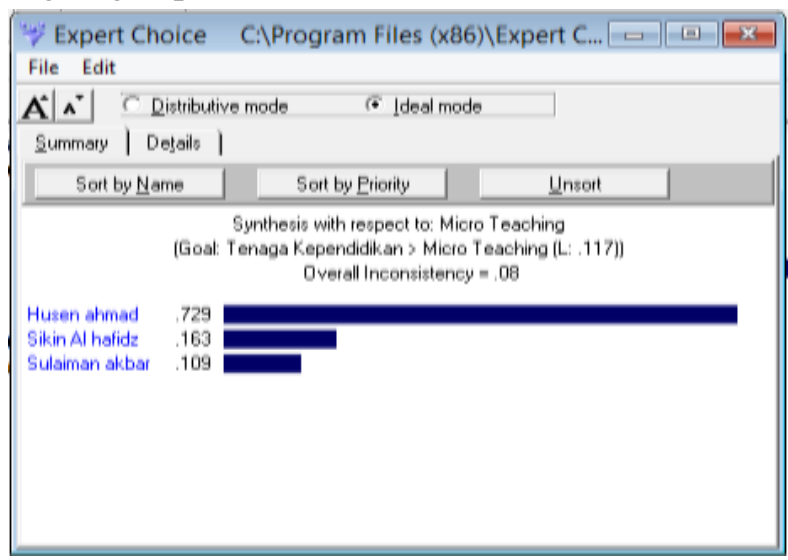

Gambar 8. Pengujian konsistensi nilai alternatif Micro Teaching pada Expert Choice

Pada pencarian penilai sebelumnya masih dilakukan secara dengan lima kriteria namun ada beberapa kriteria yang bersifat Bahasa, sedangkan untuk menentukan siapa yang memiliki tertinggi berdasarkan jumlah nilai perkeriteria dibagi dengan jumlah data sehingga yang mendapatkan rekomendasi pertama adalah alternatif yang bernama sikin al hafidz $88 \%$, alternatif kedua Sulaiman akbar $87 \%$ sedangkan alternatif yang ketiga Husen ahmad dengan nilai $85 \%$ kondisi ini tidak memiliki konsistensi data yang menyebabkan peniaian seperti personality tidak terakumulai dalam peneilaian. Sendangkan dengan menggunakna metode expert choice pencarian bobot prioritas dan bobot alternatif memiliki nilai konsisten, sehingga dapat dirangking berdasarkan ketentuan Thomas L saaty dimana setandar dari metode AHP nilai konsisten yang didapatkan dari consisten index di bagi dengan nilai indek random dengan hasil tidak lebih dari $<0.1$ persen dimana hasil prangkingan didapatkan 0.08 persen sehingga dikatakan nilai konsisten[12]. Dengan nilai altertanatif tenaga pendidik tertinggi bernama Husen ahmad dengan nilai 0.729, kedua Sikin al hafidz dengan nilai 0.163 dan Sulaiman akhbar dengan nilai 0.109. Dari hasil perangkingan ini peneliti dapat memberikan rekomendasi urutan penerimaan calon tenaga pendidik yang siap bergabung dalam meningkatkan pendidikan disekolah khairu ummah. 


\section{Kesimpulan}

Penelitian dalam mempercepat penyeleksian calon tenaga pendidik dapat peneliti simpulkan dimana yang pertama dalam proses analisis nilai masukkan yang diberikan semua konsisten baik bobot kriteria dengan konsistensi nilai 0.08, bobot administrasi konsistensi nilai 0.01 , bobot tertulis konsistensi nilai 0.003 , bobot personality dengan konsistensi nilai 0.2 , bobot wawancara dengan konsistensi 0.09 dan konsistensi bobot microteaching dengan nilai 0.08. Kedua berdasarkan proses perhitungan matrik perangkinangan dimana alternative tertinggi pada calon tenaga pendidik diproleh oleh alternatif pertama dengan nilai 0.729 bernama husen ahmad, kedua dengan nilai 0.63 bernama sikin alhafidz dan ketiga dengan nilai 0.109 bernama sulaiman akbar

\section{Daftar Pustaka}

[1] Sumiati, "Peranan Guru Kelas Dalam Meningkatkan Motivasi Belajar Siswa," $J$. Pendidik. Agama Islam, vol. 3, pp. 145-163, 2018.

[2] A. Buchari, "Peran Guru Dalam Pengelolaan Pembelajaran," J. Ilm. Iqra', vol. 12, no. 2, pp. 106-124, 2018.

[3] A. Kirom, "Peran Guru Dan Peserta Didik Dalam Proses Pembelajaran Berbasis Multikultural," Al Murabbi, vol. 3, no. 1, pp. 69-80, 2017.

[4] Suarga, "Tugas Dan Fungsi Manajemen Pendidik Dan Tenaga Kependidikan," IDARAH, vol. 23 , no. 36 , p. $1,2019$.

[5] H. Magdalena and Rani, "Desain Sistem Pendukung Keputusan Seleksi Calon Guru Sekolah Alam Berbasis Islam," Cogito Smart J., vol. 4, no. 2, pp. 358-371, 2018.

[6] W. Wisanti, "Sistem Penunjang Keputusan Penerimaan Guru Berbasis Web," Instek, vol. 2, no. 2, pp. 71-80, 2017.

[7] W. Ilmiyah, Frieyadie, and F. Handayana, "Penerapan Metode Ahp Sebagai Penunjang Keputusan penerimaan karyawan pada PT ARKONIN," Ris. Inform., vol. 1, no. 3, pp. 144-158, 2019.

[8] F. Parhusip, A. Yustika, I. Syahputri, and S. Soraya Damanaik, "Analisa metode AHP pada guru berprestasi Di SD 095130," Means, vol. 27, no. 2, p. 464, 1983.

[9] Y. Sa'adati, S. Fadli, and K. Imtihan, "Analisis Penggunaan Metode AHP dan MOORA untuk Menentukan Guru Berprestasi Sebagai Ajang Promosi Jabatan," SinkrOn, vol. 3, no. 1, pp. 82-90, 2018.

[10] H. Pratiwi, "Rancangan Penelitian Sistem Pendukung Keputusan Penerimaan Guru Honorer Di Sekolah Menengah Atas Dengan Metode Analytical Hierarchy Process," vol. 1, no. 1, pp. 108-114, 2017.

[11] S. Sembiring, "sistem pendukung keputusan pemilihan guru dengan kinerja terbaik menggunakan metode analytic network process ( anp ) ( Studi Kasus PKMI BERASTAGI )," Ris. dan J. Manaj. Inform. Komput., vol. 1, no. 1, pp. 1-8, 2016.

[12] T. Husain and A. Taufik, "Sistem Penunjang Keputusan Seleksi Guru Baru TIK Dengan Metode Analytic Hierarchy Process (AHP)," J. CENDIKIA, vol. 17, no. 1, April, pp. 251-255, 2019.

[13] S. Rakasiwi, "Sistem Pendukung Keputusan Dalam Menentukan Penilaian Kinerja Guru Dengan Metode Analytical Hierarchy Process (Ahp)," Simetris J. Tek. Mesin, Elektro dan Ilmu Komput., vol. 9, no. 2, pp. 1001-1008, 2018.

[14] L. Costaner, "Prasarana Desa Dengan Metode Analytical Hierarchy," SEMASTER, vol. 1, no. 1, pp. 112-120, 2020.

[15] R. Rachman, "Penerapan Metode Ahp Untuk Menentukan Kualitas Pakaian Jadi Di Industri Garment," J. Inform., vol. 6, no. 1, pp. 1-8, 2019.

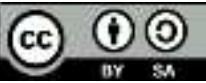

Digital Zone: Jurnal Teknologi Informasi dan Komunikasi is licensed under a Creative Commons Attribution International (CC BY-SA 4.0) 